\section{AN APPROACH TO A CASE OF CLOUDY URINE}

\author{
Aswani Rakesh,, Pokhrel Saroj** \\ Shakya Smriti ${ }^{\star \star \star}$
}

*Dr. Rakesh Aswani

Associate Professor Department of Medicine, U.C.M.S. Teaching Hospital,Ranigaon, Bhairahawa, Nepal

**Dr. Saroj Pokhrel PG Resident, Internal Medicine

${ }^{* * *}$ Dr. Smriti Shakya PG Resident, Internal Medicine

\section{A CASE REPORT}

A 34 years old female, resident of Bhairahawa, Rupandehi, presented to Medicine OPD with cloudy urine which appeared to be milky white early in the morning which became progressively clear during the day for last 6 months. It was episodic initially for some months which later became continuous. She visited two of the local physicians and was empirically treated with steroids for 2 months with no change in symptoms. She reported no pain abdomen, burning micturition, vomiting, frequency, urgency, diarrhea or constipation, swelling of body, cough, breathlessness, anorexia, malaise, weight loss, trauma or surgery, per vaginal discharge. No history of travel. She has two children born via normal vaginal delivery, youngest aged 2 years. Family history and past history insignificant.

On clinical examination, there was no pallor, icterus, lymphadenopathy, clubbing, oedema. But she had steroid induced cushingoid features. Her blood pressure was $140 / 90 \mathrm{mmHg}$, pulse 80 bpm regular, afebrile, respiratory rate $16 /$ min.

On systemic examination, there were no abnormal findings in respiratory, cardiovascular, abdominal and nervous system.

The laboratory parameters revealed:

Haematology:

Hemoglobin-12gm\%, complete blood count 10,100/cu mm, differential count P70 L23 E5 M2 B0, ESR $40 \mathrm{~mm} / \mathrm{hr}$

\section{Biochemistry:}

Blood Urea $35 \mathrm{mg} \%$, Serum creatinine $1.1 \mathrm{mg} \%$, Random blood sugar $114 \mathrm{mg} \%$, Liver function test were within normal limits, Fasting lipid profile within normal limits, 24 hour urinary protein $<1.5 \mathrm{gm}$, Urinary Triglycerides $560 \mathrm{mg} \%$

Chest X-ray and ECG were within normal limits.

Urine RME:

\begin{tabular}{|l|l|l|}
\hline & $\begin{array}{l}\text { Morning } \\
\text { sample }\end{array}$ & $\begin{array}{l}\text { Evening } \\
\text { sample }\end{array}$ \\
\hline Physical & & \\
\hline Colour & $\begin{array}{l}\text { Milky } \\
\text { white }\end{array}$ & $\begin{array}{l}\text { Light } \\
\text { yellow }\end{array}$ \\
\hline Appearance & Turbid & Clear \\
\hline & & \\
\hline
\end{tabular}




\begin{tabular}{|l|l|l|}
\hline Chemical & & \\
\hline Reaction & Alkaline & Alkaline \\
\hline Albumin & ++++ & Nil \\
\hline Sugar & Nil & Nil \\
\hline Microscopy & & \\
\hline Pus cells & $4-6 / h p f$ & Nil \\
\hline RBCs & Plenty/hpf & Nil \\
\hline Epi. Cells & $10-12 / h p f$ & $5-6 / h p f$ \\
\hline Casts & Nil & Nil \\
\hline Lymphocytes & Present & Absent \\
\hline
\end{tabular}

Microbiology:

Urine culture and sensitivity- no growth of organism in 24, 48 and $72 \mathrm{hrs}$ of incubation

Malarial parasite- negative,

rk-39- negative

Filarial antigen positive

Microfilaria seen in urine and peripheral blood smear

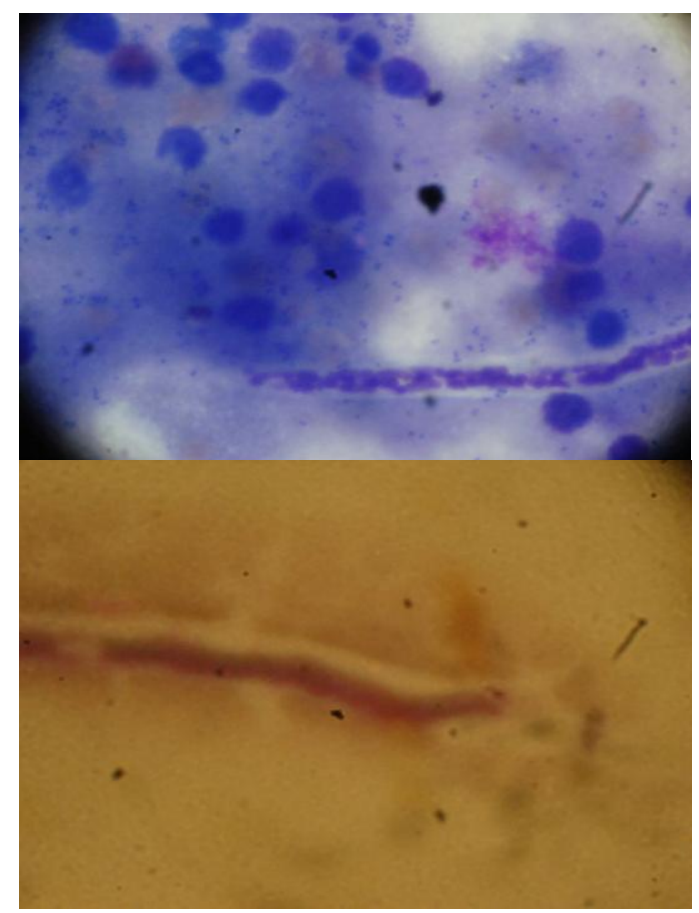

\section{DISCUSSION}

Chyluria, recognized since the time of Hippocrates (400BC) is described as the passage of milky appearing white urine due to the presence of chyle composed of albumin, emulsified fat and fibrin in varying proportions that are absorbed by intestinal lacteals. It is associated with spontaneous remissions and exacerbations ${ }^{1,2}$. It is recognized as a urological manifestation of lymphatic system abnormality, which is commonly caused by filariasis. Lymphatic filariasis is caused by Wuchereria bancrofti, Brugia malayi, or Brugia timori. It has been recognized as a tropical disease more prevalent in the rural and poverty stricken population ${ }^{2,7}$.

\section{Classification:}

The classification of chyluria is based on the etiological factors- broadly divided into two groups, parasitic and non parasitic ${ }^{2,5,6}$ 
Table1. Classification of chyluria based on etiological factors

\begin{tabular}{ll}
\hline Parasitic (primary-tropical) & Non-parasitic (secondary-nontropical) \\
\hline - Wuchereria bancrofti $(90 \%)$ & - Congenital \\
- Taenia echinococcus & - Lymphangioma of urinary tract \\
- Taenia nana & - Megalymphatics \& urethral/vesical fistulae \\
- Ankylostomiasis & - Stenosis of thoracic duct \\
- Trichiniasis & - Retroperitoneal lymphangiecatasia \\
- Malarial parasites & - Traumatic lymphangiourinary fistulae \\
& - Obstruction of thoracic duct/lymphatics (tumor, granulomas, aortic aneurysm) \\
& - Nephrotic syndrome \\
\hline
\end{tabular}

\section{Grading:}

The severity of the disease can be graded into ${ }^{1,15}$ :

Mild chyluria (34-50\%): Intermittent milky urine; no clot colic/chylous coagulum/urinary retention/weight loss; involvement of single calyx on Retrograde Pyelography (RGP).

Moderate chyluria (33- $40 \%)$ : Intermittent continuous milky urine with occasional clot colic/chylous coagulum; no urinary retention/weight loss; involvement of 2 or more calyces on RGP.

Severe chyluria (15-26\%): Continuous milky urine with clot colic/chylous coagulum/urinary retention /weight loss; involvement of most of calyces with/without involvement of ureter on RGP.

Microfilaria were found in blood sample collected at night because $W$. bancrofti is a periodic strain that exhibits nocturnal periodicity i.e. during the day, they are present in the deep veins, and during the night, they migrate to the peripheral circulation ${ }^{14}$.
In our patient, the urine sample was milky white early in the morning due to stasis in the lymphatic flow during sleep that led to lymphatic fluid drain into the lymphatic channel of the urinary system from the intestinal lymphatics in a retrograde fashion.

Presence of protein in the early morning sample of urine can be explained because of lymphatic fluid rich in albumin. Albuminuria in case of chyluria is nonselective in comparision to selective protineuria seen in nephroitic syndrome, confirmation of which requires urine protein electrophoresis and renal biopsy. That was the reason the patient was primarily treated in the line of nephrotic syndrome by a local physician. However, absence of proteinuria later in the urinary sample as the day progresses, absence of edema, proteinuria $<3.5 \mathrm{gm} / \mathrm{dl}$ and normal blood cholesterol level rule out possibility of nephrotic syndrome. 
Comparison of Nephrotic proteinuria and Chylous proteinuria ${ }^{13}$

\begin{tabular}{|c|c|c|}
\hline & $\begin{array}{l}\text { Nephrotic } \\
\text { proteinuria }\end{array}$ & $\begin{array}{l}\text { Chylous } \\
\text { proteinuria }\end{array}$ \\
\hline $\begin{array}{l}\text { Onset and time } \\
\text { course }\end{array}$ & $\begin{array}{l}\text { Gradual } \\
\text { and } \\
\text { persistent } \\
\text { Increased } \\
\text { with high } \\
\text { protein diet }\end{array}$ & $\begin{array}{l}\text { Episodic } \\
\text { with } \\
\text { remissions } \\
\text { Increased } \\
\text { with fatty } \\
\text { meal }\end{array}$ \\
\hline $\begin{array}{l}\text { Flank pain and } \\
\text { renal colic }\end{array}$ & Unusual & Frequent \\
\hline Hypertension & $\begin{array}{l}\text { May be } \\
\text { present }\end{array}$ & Unusual \\
\hline Pitting edema & Present & $\begin{array}{l}\text { Only present } \\
\text { in mal- } \\
\text { nourished } \\
\text { patient }\end{array}$ \\
\hline $\begin{array}{l}\text { Hypo- } \\
\text { albuminemia }\end{array}$ & Present & $\begin{array}{l}\text { Only present } \\
\text { in mal- } \\
\text { nourished } \\
\text { patient }\end{array}$ \\
\hline Hyperlipidemia & Common & Unusual \\
\hline $\begin{array}{l}\text { Cloudy and } \\
\text { milky urine }\end{array}$ & Rare & Typical \\
\hline Clots in urine & Rare & Common \\
\hline $\begin{array}{l}\text { Gross } \\
\text { hematuria }\end{array}$ & Rare & $\begin{array}{l}\text { May be } \\
\text { present }\end{array}$ \\
\hline $\begin{array}{l}\text { Micro- } \\
\text { hematuria }\end{array}$ & $\begin{array}{l}\text { May be } \\
\text { present }\end{array}$ & Common \\
\hline
\end{tabular}

\begin{tabular}{|c|c|c|}
\hline $\begin{array}{l}\text { Morphology of } \\
\text { urinary } \\
\text { erythrocytes }\end{array}$ & Dysmorphic & Isomorphic \\
\hline $\begin{array}{l}\text { Urinary } \\
\text { lymphocytes }\end{array}$ & Absent & Present \\
\hline Urinary casts & $\begin{array}{l}\text { May } \\
\text { contain red } \\
\text { cell cast, } \\
\text { fatty cast } \\
\text { or cellular } \\
\text { cast }\end{array}$ & $\begin{array}{l}\text { No casts or } \\
\text { cylindroids } \\
\text { seen }\end{array}$ \\
\hline $\begin{array}{l}\text { Urine protein } \\
\text { electrophoresis }\end{array}$ & $\begin{array}{l}\text { Mainly } \\
\text { albumin }\end{array}$ & $\begin{array}{l}\text { Albumin, } \\
\text { globulin, and } \\
\text { lipoprotein }\end{array}$ \\
\hline Lipids in urine & $\begin{array}{l}\text { Fatty } \\
\text { droplets, } \\
\text { oval fat } \\
\text { bodies, } \\
\text { fatty casts } \\
\text { in urine } \\
\text { sediment }\end{array}$ & $\begin{array}{l}\text { No oval fat } \\
\text { bodies or } \\
\text { fatty casts in } \\
\text { urine } \\
\text { sediment } \\
\text { Chylomicron } \\
\text { and } \\
\text { triglycerides } \\
\text { are in the } \\
\text { supernatant } \\
\text { Increase in } \\
\text { urine } \\
\text { triglyceride } \\
\text { after a fatty } \\
\text { meal }\end{array}$ \\
\hline Renal function & $\begin{array}{l}\text { Normal or } \\
\text { decreased }\end{array}$ & Normal \\
\hline
\end{tabular}


Urinary level of triglyceride is usually high after a fatty meal or in the fresh early morning milky urine sample.

The presence of chyle in the urine can be confirmed by shaking an aliquot of turbid urine with equal volume of chloroform or ether, which extracts the triglyceride-rich fatty emulsion into the organic layer, leaving the remaining urine clear ${ }^{6,8,9}$.The diagnosis of chyluria can also be confirmed by demonstrating a timed increase in the excretion of urinary triglyceride approximately $4 \mathrm{~h}$ after a fatty meal. The presence of lymphocytes in the urinary sediment is also consistent with the presence of chyle in the urine ${ }^{10,11,12}$.

In our patient, hematuria may be due to rupture of minute blood vessels at the fistulous site.

Other possibilities of cloudy urine like UTI, nephrotic syndrome, renal calculi, per vaginal discharge, etc. are less likely possible as the patient is asymptomatic except the passage of milky white urine early in the morning whereas the urine parameters were normal in subsequent sample during the day.

Further evaluation of chyluria includes localization of the side, the site, and the level of lymphatic urinary fistula, and the assessment of the underlying etiology. This is best achieved by performing cystoscopy after a fatty meal, allowing the identification of the ureteral orifice that is passing milky urine or a site of chylous efflux into the bladder or urethra. This is followed by lymphangiography for the detection of the level and site of lymphatic urinary fistula formation ${ }^{10,11}$. Although lymphangiography is the procedure of choice for localization of lymphatic urinary shunt, it requires cannulation of small lymphatic vessels in the foot and injection of lipid contrast medium (Ethiodol) into the lymphatic system, followed by serial pelvic and abdominal radiography for visualization of lymphatics and lymph nodes in the pelvic, retroperitoneal, and para-aortic regions ${ }^{12,13}$. In patients with chyluria, lymphangiography typically shows marked dilatation and tortuosity of the lymphatics around the hilar regions of the kidneys, followed by opacification of the calyceal systems. In a minority of patients, the lymphatic urinary communication may be seen at the level of ureter or urinary bladder. It should be noted that the procedure of lymphangiography is technically challenging, requiring a skilled operator, and is not without complications ${ }^{3,4}$.A non-invasive and equally accurate lymphoscintigraphy has been increasingly utilized for the evaluation of chyluria; it allows the clear and precise analysis of the lymphatic system function in patients with filarial infection.

The patient has been started on Diethylcarbamazine and planned for above mentioned investigation at a later date. 


\section{REFERENCES}

1. Int J NephrolUrol, 2009; 1(1): 14 26Chyluria - An OverviewSachit Sharma, Ashok Kumar Hemal*Department of Urology, All India Institute of Medical Sciences, New Delhi, India

2. iMedpubjournals:Archieves of clinical Microbiology (2012 Vol.3No.4:1doi:10:3823/255) Saha $P$, Sarkar S, SarkarD,SenGupta M. A Case Report of Chyluria with Proteinuria Filarial origin? An Enigma

3. Seth $A$ (2009) Microfilaruria in a patient of intermittent chyluria. J Cytol 26:151-52.

4. Intermittent Chyluria: Case Report: TuabaGün, Ali Çelik, SerkanYıldız, Caner Çavdar, CananÇoker, YiaitGöktay, RecepBekiflAykutSifil, TanerÇamsar> 2005;14 (3) 140-142

5. Szuba A, Rockson SG (1998) Lymphedema, Classification, diagnosis and therapy. Vascular Med 3:145-56.

6. Peng HW, Chou CF, Shiao MS, Lin $E$, Zheng HJ, Chen CC, et al. Urine lipids in patients witha history of filariasis. Urol Res. 1997;25(3):217-21.

7. Indian J Nephrol. 2012 MarApr; 22(2): 147-148. doi: 10.4103/09714065.97142

Easy method of detection of chyle in urine Md. M. Rahman

8. mauchi S. Chyluria: clinical, laboratory and statistical study of 45 personal cases observed in Hawaii. J Urol 1945; 54: 318347.

9. Diamond E, Schapira HE. Chyluria - a review of the literature. Urology 1985; 26 : 427-431.
10. oo CG, Van Langenberg A. Chyluria. A clinical study.J R CollSurgEdinb 1969; 14: 31-41.

11. kisada M, Tani S. Filarial chyluria in Japan. Lymphography, etiology and treatment in 30 cases. Radiology 1968; 90: 311-317.

12 .Kittredge RD, Hashim S, Roholt HB et al. Demonstration of lymphatic abnormalities in a patient with chyluria. Am J Roentgenol 1963; 90: 159-165.

13. intractablechyluria. J Urol. 2002 Jun;167(6):2473-6. 